\title{
ACTUALITATEA PENTALOGULUI UNIVERSITAR AL LUI VASILE BOGREA
}

DOI: $\quad 10.24193 /$ SUBBiur.65(2020).2.5

Paul Popovici*

„A fi obiectiv nu înseamnă, nu poate să însemne a înceta să fii om¹."

Rezumat: Profesorul Vasile Bogrea a fost o stea cât o constelaţie în primii ani de după Primul Război Mondial. Poliglot impresionant prin numărul de limbi stăpânite - fiind, „după Haşdeu, cel mai pregătit dintre lingviștii români pentru lingvistica comparativă” - poseda uluitoare cunoștințe enciclopedice și o memorie comparabilă cu cea a lui Nicolae Iorga. La aproape 100 de ani de la prematura sa moarte, opera, inclusiv cea etică, cu toată întinderea ei redusă, rezistă probei timpului, făcând dovada unei minți strălucitoare, care cândva îi fermecase pur şi simplu pe contemporanii săi. Între însemnările lui Vasile Bogrea publicate postum se găsește un pentalog universitar, un veritabil cod moral in nuce, care sintetizează în formulări memorabile principii perene.

Articolul de față analizează acest pentalog încercând să reliefeze modul în care ,articolele” sale se regăsesc în prevederile Codului de etică al Universității Babeș-

* Conf. Univ. Dr. la Universitatea Creștină „Dimitrie Cantemir” Bucureşti, Facultatea de Drept din Cluj-Napoca; avocat. Adresa de corespondență: paul.popovici@pedagogia.ro. Prezentul articol reprezintă versiunea revăzută a comunicării Vasile Bogrea. Prolegomene la o etică a cercetării știïțifice, susținută online în 22 mai 2020 studenților de la Școala Doctorală de Geografie din cadrul Facultăţii de Geografie a Universității Babeș-Bolyai.

${ }^{1}$ Vasile Bogrea, Sine ira et studio, în Mircea Borcilă, V. M. Ungureanu (ed.), „Sacra Via. Pagini literare și publicistică”, Ed. Dacia, Cluj, 1973, p. 80. 
Bolyai, numele actual al instituției de învățământ superior al cărei strălucit profesor a fost, între 1919 și 1926, Vasile Bogrea.

Recuperarea pentalogului la nivel instituțional, ca preambul al Codului de etică, ar însemna asumarea unei tradiții morale de cea mai bună factură de către una dintre cele mai mari și mai prestigioase instituții de învățământ superior din România.

Cuvinte cheie: cod de etică, universitate, morală, memorie

\title{
THE ACTUALITY OF VASILE BOGREA'S UNIVERSITY PENTALOGUE
}

\begin{abstract}
Professor Vasile Bogrea was the most prominent star in a constellation of academics in the first years after the First World War. Impressive polyglot - being, according to Hasdeu, 'the most skilful in comparative linguistics of all Romanian linguists' -, he possessed an amazing encyclopaedic knowledge and a memory comparable with Nicolae Iorga's. Nearly a century after his untimely death, Bogrea's work, including the ethical one, despite its limited extent, withstands the test of time, testifying for a brilliant mind that had once simply charmed its contemporaries. Among Vasile Bogrea's notes, a university pentalogue was posthumously published, a true moral code in a nutshell, which synthesizes in sparkling formulations some perennial principles.

This article analyses the provisions of the pentalogue, showing that their essence is to be found in the provisions of the Code of Ethics of Babess-Bolyai University, the current name of the higher education institution whose brilliant professor was, between 1919 and 1926, Vasile Bogrea.

The re-discovery of the pentalogue at the institutional level as a preamble of the Code of Ethics would imply the shouldering of a moral tradition of the best bill by one of the largest and most prestigious higher education institutions in Romania.
\end{abstract}

Keywords: code of ethics, university, morals, memory

\section{Nevoia de umanitate}

Desigur că putem diseca, analiza, interpreta și reinterpreta orice dispoziție din codurile de etică universitară, dar nu trebuie să uităm că aceste 
dispoziții privesc oameni și au fost asumate avant la lettre tot de oameni. De aceea, se impune în primul rând cultivarea valorilor morale ${ }^{2}$ astfel încât respectarea lor să devină conținutul propriu-zis al conștiinței, iar aplicarea lor, un act mecanic 3 . Acesta este de fapt scopul eticii, crearea de tipare de integritate, nu de a fi o știință între cele care doar informează. Iar modelele sunt mai mult decât necesare pentru tineri: „Aspirațiile pe care le au pot să fie determinate sau susținute prin puterea exemplului altora: Iată că se poate4!”. Iată de ce rolul eticii este unul de o importanță la fel de mare ca şi cel al disciplinelor care asigură cunoștințele profesionale: „Etica este știința normativă cea mai înaltă, care închide seria științelor sociale explicative şi normative5”. De altfel, după cum s-a spus, ,„̂ntre caracter și inteligență n-ar trebui să existe alegere; inteligența o găsești prea des, caracter prea puțin ${ }^{6}$."

2 Având în vedere abordări similare, datorită suprapunerii lor conceptuale, vom considera cei doi termeni - morala și etica - ca fiind sinonimi. A se vedea în acest sens, Peter SINGER, Introducere, în „Tratat de etică”, trad. coord. Vasile BOARI, Raluca MĂRINCEAN, Ed. Polirom, Iași, 2006, p. 17; Christopher PANZA, Adam PotThast, Ethics For Dummies, Wiley Publishing, Hoboken (NJ), 2010, p. 11; Élisabeth CLÉMENT ş. a., Filosofia de la A la Z, trad. M. COJOCEAMĂrculescu, A. CoJoceA, Ed. All Educational, București, 1999, p. 166. Pentru o explicație sintetică privind deosebirile dintre cei doi termeni, a se vedea ibidem, p. 167-168; Anthony FLEW (coord.), Dicționar de filozofie și logică, ed. a II-a, trad. D. StoranovicI, Ed. Humanitas, București, 1999, p. 118-120.

3 Nicolae MăRgineanu, Condiția umană, Ed. Științifică, București, 1973, p. 122 și urm.

4 Paul Popovici, Silviu Iordan a fost un exemplu pentru noi, în Titus Sucıu, Vasile Bogdan, „Noi, cei de la Loga, în oglinda veacului”, Ed. Artpress, Timișoara, 2019, p. 609, reluat în Vasile Bogdan, Paul Popovici, „Eroii nu mor niciodată”, în Cosmin ANDREICA ș.a., Silviu-Sebastian Iordan. In memoriam, in perpetuam memoriam (1971-1989), Ed. Argonaut, Cluj-Napoca, 2019, p. 45 .

5 Dimitrie Gusti, Opere, vol. I, ed. Ovidiu Bădina, Octavian NeAmȚu, Ed. Academiei Republicii Socialiste România, București, 1968, p. 221.

6 Mihai EmInescu, citat după Constantin NoICA, Introducere la miracolul eminescian, Ed. Humanitas, București, 2003, p. 69. 
Or, scopul disciplinei este „formarea și realizarea voinței celei mai bune, a voinței către o personalitate desăvârșită ${ }^{\prime \prime}$.

Prin urmare, dincolo de prevederile Legii educației naționale ${ }^{8}$, de competențele generale și specifice, profesionale și transversale, obiective specifice, detaliate sau nu în fişa disciplinei, scopul final al eticii este acela de a fundamenta moral ființa umană pentru că „fără o centrare morală toate celelalte însușiri umane se dezgolesc de sens și se degradeazăa".

De aceea, introducerea în planul de învățământ a disciplinei Etică şi integritate academică ${ }^{10}$ constituie o oportunitate specială pentru formarea caracterului studenților. De cele mai multe ori fiind, presaţi de timp să îşi parcurgă materia şi neținând de domeniul fiecărei materii de studiu, profesorii nu teoretizează și chestiunile care constituie, în fond, canavaua pe care se construiește un profesionist: moralitatea. În urma orelor şi examenelor rămâne aproape mereu doar exemplul personal și viu al fiecăruia, deloc de neglijat, firește.

Între cei care pot constitui un model prin probitatea științifică și moralitatea personală, oare Vasile Bogrea constituie un etalon prea îndepărtat? La aproape un secol de la moartea sa, personalitatea și opera lui sunt, parcă, din ce în ce mai puțin cunoscute, deși această uitare este

7 Dimitrie Gust, Opere, vol. II, ed. Ovidiu BăDInA, Octavian NEAmȚu, Ed. Academiei Republicii Socialiste România, București, 1969, p. 39.

${ }^{8}$ Legea nr. 1/2011 a educației naționale, publicată în Momitorul oficial al României, nr. 18 din 10 ianuarie 2011, A se vedea în acest sens dispoziția art. 4 lit. f) privind „cultivarea sensibilității față de problematica umană, față de valorile moral-civice și a respectului pentru natură și mediul înconjurător natural, social și cultural”.

9 Ernest BerneA, Trilogie pedagogică, Ed. Dacia, Cluj-Napoca, 2002, p. 116.

10 Ordinul ministrului Educației Naționale nr. 3.131/2018 privind includerea în planurile de învățământ, pentru toate programele de studii universitare organizate în instituțiile de învățământ superior din sistemul național de învățământ, a cursurilor de etică și integritate academică, publicat în Monitorul oficial al României, nr. 140 din 14 februarie 2018. 
nedreaptă. Ce anume îl recomandă și care îi sunt contribuțiile la materia eticii academice?

\subsection{Biografia lui Vasile Bogrea}

S-a născut la 26 septembrie 1881, în comuna Târnauca, județul Dorohoi (astăzi în Ucraina). A urmat Facultatea de Litere şi Facultatea de Drept din Iaşi (1902-1906) și, mai târziu, a audiat cursuri de filologie clasică la Berlin cu cei mai eminenți reprezentanți ai domeniului, unii chiar din toate timpurile (1910-1914); studiile berlineze le-a întrerupt din cauza războiului ${ }^{11}$.

A devenit lingvist și „filolog de excepțională rigoare ${ }^{12 ”}$, poet și traducător, profesor universitar la Catedra de Limbi Clasice a Facultăţii de Litere și Filosofie a Universităţii din Cluj (începând din anul 1919, fiind unul dintre profesorii întemeietori ai instituției), membru corespondent (din 1920) al Academiei Române ${ }^{13}$.

Activitatea sa nu s-a rezumat doar la catedră; s-a implicat activ în culturalizarea mediului urban din Transilvania: alături de alții, a înființat Extensiunea universitară ${ }^{14}$. Totodată, alături de Sextil Puşcariu, a pus bazele

${ }^{11}$ Pentru detalii, a se vedea, de exemplu, Eugen Simion, Dicționarul general al literaturii române, vol. I, A-B, Ed. Univers Enciclopedic, București, 2007, p. 580-581.

${ }^{12}$ Mircea Anghelescu, Vasile Bogrea, în Aurel SAsu, „Dicţionar biografic al literaturii române”, vol. I, „A-L”, Ed. Paralela 45, Pitești, 2006, p. 181.

13 Pentru detalii privind primirea ca membru corespondent al Academiei Române, a se vedea Vasile PÂRVAN, Raport asupra activității ștïnțifice a dlui V. Bogrea, în „Scrieri”, Ed. Științifică și Enciclopedică, București, 1981, p. 240.

14 Pentru detalii privind „Extensiunea Universitară” și în special rolul ei de culturalizare asumat de profesorii Almei Mater clujene în orașele și orășelele transilvănene, a se vedea, de exemplu, Virgil I. BĂRBAT, Extensiunea universitară, Tiparul Tipografiei „Înfrățirea”, Cluj, 1925, p. 7-49. 
Muzeului Limbii Române (1919)15 și Societăţii Etnografice din Cluj (1923), fiind unul dintre cei mai activi membri ai acestor instituții.

A decedat la 8 septembrie 1926 într-un spital din Viena, în urma unei operații nereuşite (nu trebuie uitat că la vremea aceea riscurile operatorii erau majore). Prin testament a transmis universităţii clujene un fond bogat de carte ${ }^{16}$, o arhivă, precum și o sumă de bani ${ }^{17}$.

Memoria lui Vasile Bogrea este păstrată prin denumirea a două săli de curs cu numele său (Facultatea de Litere, respectiv de Istorie şi Filosofie din cadrul Universităţii Babeș-Bolyai) sau prin denumiri de străzi (în Arad, Botoşani şi Cluj-Napoca). De asemenea, au fost publicate articole comemorative $^{18}$ ori au fost dedicate lucrări amintirii sale ${ }^{19}$, iar la 10 ani de la

\footnotetext{
15 „Muzeul” se numește astăzi Institutul de Lingvistică și Istorie Literară „Sextil Pușcariu”. 16 „Anuarul Institutului de Istorie Națională”, IV/1926-1927, p. VI.

17 „Lăsământul « V. Bogrea », în sumă de 76.207 lei” - „Anuarul Universității Regele Ferdinand I Cluj-Sibiu în al doilea an de refugiu 1941-1942”, p. 475-476. Pentru dispozițiile pentru cauză de moarte - „care lasă de la sine să se portretizeze noblețea sufletească” a testatorului- , a se vedea Lucian NASTASĂ, Testamentul lui Vasile Bogrea, în „Dacia literară”, nr. 2/1996, p. 28. În fapt, este vorba de o scrisoare redactată de Vasile Bogrea și adresată lui Alexandru Lapedatu (un mare susținător al savantului). Aceasta, în conformitate cu dispozițiile art. 859 Cod civil 1864, putea să reprezinte o formă validă de testament - Dimitrie ALEXANDRESCO, Explicațiunea teoretică şi practică a dreptului civil român, tom. IV, partea a II-a, Testamentele (art. 856931), ed. a II-a, revăzută, corectată și mărită considerabil, Ed. Atelierele Grafice Socec, București, 1914, p. 42.

18 Dintre cele mai cunoscute personalități care au scris în acest sens, menționăm pe Ion AgÂrbiceanu, Theodor Capidan, Șerban Cioculescu, Silviu Dragomir, Nicolae Drăganu, Alexandru Graur, Nicolae Iorga, Adrian Marino, Perpessicius, Ioan Petrovici, Sextil PușCariu, Alexandru Rosetti, Eugeniu Sperantia, George VÂlSAN - a se vedea Despre Vasile Bogrea (bibliografie selectivă), în Vasile BOGREA, SACRA VIA, p. 284-289.

19 De exemplu, N. BĂNESCU, Chipuri și scene din Bizanț, Tipografia Cartea Românească, Cluj, 1927, 185 p.; Dimitrie URZICĂ, Sate și tîrguri de pe înaltul podiş al Dorohoiului, București 1928, apud Dări de seamă, în „Revista Istorică”, nr. 4-6/1928, p. 212.
}

118 
moartea sa a apărut o biobibliografie ${ }^{20}$ și abia în urmă cu 10 ani a fost tipărită prima monografie despre savant ${ }^{21}$. Târziu au văzut lumina tiparului volume care includ scrieri reeditate şi inedite ori scrisori. Însemnări privind personalitatea lui Vasile Bogrea se întâlnesc și în corespondența unor terțe persoane, chiar la mult timp după moartea sa ${ }^{22}$.

Trebuie amintit și faptul că, la un moment dat, Liga Culturală a susținut financiar o bursă „Vasile Bogrea” în cadrul Universității din Cluj²3.

\section{Honor est præmiun virtutis ${ }^{24}$}

După stingerea din viață a lui Vasile Bogrea, Nicolae Iorga a scris: „A murit un om cum, poate, niciodată nu vom mai avea altul. Nația noastră a pierdut o comoară. Era cel mai învățat dintre români. Era un neîntrecut

20 În fond o listă a articolelor și recenziilor profesorului, publicate antum sau postum Iosif E. NAGHIU, Biobibliografia lui Vasile Bogrea (1881-1926). Cu ocazia a 10 ani de la moartea sa, Tipografia „Cartea Românească”, Cluj, 1937, p. 17-33 Broșura se deschide cu o cuvântare comemorativă de T. A. NAuM, Zece ani de la moartea lui V. Bogrea, apărută și în „Gând românesc", nr. 10-11/1936, p. 505-510.

${ }^{21}$ C. N. Minalache, Vasile Bogrea: omul, profesorul, publicistul, Ed. Aura, Timişoara, 2010, $73 \mathrm{p}$.

22 De exemplu: „Noi am avut cândva un mare etimologist - cum n-a mai fost - , căci în precizie şi logică îl întrecea pe Hajdău - şi cum poate nu va mai fi. Acest maestru în adevăr inegalabil al etimonului a fost Vasile Bogrea. Tot ce a scris el în această direcție - până la cea mai măruntă notiță - constituie un model al genului” - Petru CARAMAN, scrisoare din 20 ianuarie 1956, în G. T. KiRILEANu, Corespondență, ed. Mircea Handoca, Ed. „Minerva”, București, 1977, p. 401, citat după I. MĂRII, Note şi studii de etimologie lexicală dacoromână, Ed. Academiei Române, București, 2005, p. 173.

23 Diverse, în „Societatea de Mâine”, nr. 18/1927, p. 230.

24 Lat.: „onoarea este răsplata virtuții” - CiCERO, Ad Brutum, 81, 281, citat după Virgil MATEI, Dicționar de maxime, reflecții, expresï latine comentate, Ed. Scripta, București, 1998, p. 113. 
vorbitor și un profesor fără pereche. Era un caracter vrednic de vremile antice. Era, în suferința lui de atîția ani de zile, un sfînt ${ }^{25}$."

$\mathrm{Nu}$ doar polihistorul a împărtășit posterității rânduri emoționante despre profilul intelectual pe care l-a avut profesorul clujean. Astfel, acesta a fost numit „un ascet al științei, în adâncul înțeles al cuvântului”, iar dispariția lui a fost deplânsă pentru că „moartea prea timpurie nu i-a dat răgaz să realizeze decât o prea mică parte din opera pe care numai el ar fi fost în stare s-o ducă la bun sfârșite"

\subsection{Opera științifică a lui Vasile Bogrea}

Aprecieri pertinente asupra operei sale pot avea numai cei din specializarea sa ori, mai bine spus, din specializările sale, persoane avizate asupra conținutului și a surselor utilizate; de aceea ne-am mărginit doar la a consemna ceea ce alții au notat. Cu toate acestea, este impresionant și pentru un nespecialist enormul aparat critic, iar formulările şi raționamentele sale sunt seducătoare. Cât privește greșelile de interpretare pe care le-a avut, s-a observat că de acestea „nu scapă în întregime absolut nimeni27”.

În raport cu înzestrarea intelectuală a lui Vasile Bogrea, opera sa științifică este modestă ca întindere ${ }^{28}$. Cu toate acestea, „practic, contribuția lui V. Bogrea la etimologia (lexicală) românească este, cantitativ şi calitativ

\footnotetext{
25 Nicolae Iorga, Oameni cari au fost, vol. II, ed. Ion Roman, Edit pentru Literatură, București, 1967, p. 231.

${ }^{26} \mathrm{Nu}$ am identificat vreun panegiric din care să lipsească evocarea dimensiunii intelectuale rare pe care a avut-o Vasile Bogrea: „Era unul din acei intelectuali de rasă, cum puțini am avut vreodată în țara noastră” - ȘT. BEZDECHI, Vasile Bogrea, în „Societatea de mâine”, nr. 3940/1926, p. 625.

27 Iorgu IoRDAN, Vasile Bogrea (1881-1926), în „Cercetări de lingvistică”, nr. 1/1977, p. 15. ${ }^{28}$ Ibidem, p. 11.
} 
evaluată, imensă, chiar dacă nu absolut toate etimologiile propuse de el sunt întru totul convingătoare, ceea ce, evident este un lucru cât se poate de normal pe terenul atât de dificil (pentru specialist, desigur) al etimologiei (lexicale)29".

Totodată opera sa științifică e inegală ca dimensiune, dacă este să fie avut în vedere reperul încadrării ca profesor universitar. Până atunci el a publicat foarte puțin, însă dobândise o notorietate atât de mare în cercurile științifice, încât a fost propus pentru postul de profesor agregat (de latină la Facultatea de Litere) atunci când s-a înființat Universitatea românească din Cluj, în anul 1919, iar un an mai târziu, în 1920, a fost ales membru corespondent al Academiei Române. În calitate de universitar, în ultimii şase ani din viață el a publicat de zece ori mai multe articole față de perioada precedentă ${ }^{30}$. „Prinț al erudiției ${ }^{31}$ ”, contribuțiile sale științifice sunt foarte dense şi variate, ele privind istoria limbii, lexicologia, etimologia, toponimia, antroponimia și folclorul ${ }^{32}$.

Vom menționa doar două articole antume care privesc dreptul, mai exact istoria dreptului românesc şi anume: „Din vechea terminologiejuridică: Ferîie” și „Despre ferâie33”. De ce acestea sunt importante, cu toată

29 I. MĂRII, op.cit., p. 173.

30 D. MACREA, Un mare umanist român: Vasile Bogrea, în „Cercetări de lingvistică”, nr. 2/1965, p. 250-251 (reluat în D. MACREA, Un mare umanist român: Vasile Bogrea, în „Studii de lingvistică română”, Ed. Didactică și Pedagogică, București, 1970.

$3^{1}$ Mircea BorcILĂ, Ion MĂRII, Introducere, în Vasile Bogrea, „Pagini istorico-filologice”, ed. Mircea Borcilă, Ion MăRII, Ed. Dacia, Cluj, 1971, p. XVI.

$3^{2}$ Vasile Bogrea avea un „spirit de o universalitate atât de pronunțată, pentru care lingvistica, istoria, etnografia, folclorul și literatura alcătuiau diferitele fețe ale aceluiaşi întreg: istoria culturală” - Sextil PușCARIU, Vasile Bogrea, în „Dacoromanica”, IV/1924-1926, partea a II-a, p. 1530. A se vedea și Iordan DAtcu, Sabina-Cornelia Stroescu, Dicționarul folcloriștilor. Folclorul literar românesc, Ed. Științifică și Enciclopedică, București, 1979, p. 79-80.

33 Vasile BOGREA, Din vechea terminologie juridică: Ferîie, în „Anuarul Institutului de Istorie Națională”, II/1923, p. 345-350, idem, în Despre ferâe, în „Anuarul Institutului de Istorie Națională”, III/1924-1925, p. 520-521. 
dimensiunea lor redusă? Pentru că lămuresc, fără echivoc, etimologia cuvântului. „Asupra originii acestui termin arhaic, ca şi asupra naturii înseşi a instituțiunii pe care o denumește, există o întreagă literatură, la care au colaborat istorici (Xenopol, Bogdan, Iorga), jurişti (Paşcanu, Tanoviceanu), filologi (Tiktin), culegători de documente (Ghibănescu)", controversa devenind, după remarca lui Bogrea, „numai mai stufoasă, și mai spinoasă”. El însă o rezolvă în baza cunoștințelor sale de filologie comparată și istorică ${ }^{34}$ (mai târziu avea să îşi nuanțeze interpretarea35). Bogrea nu a dorit să intre în polemici privind disputa juridică asupra naturii instituției feriei ${ }^{36}$ și a conținutului acesteia pentru că îi lipsea nu doar „materialul documentar complet, ci și competența necesară 37 ( rara avis!). Va consemna însă ceea ce s-a scris esențial până la el în această problemă, părând a fi favorabil totuși prin spațiul mai generos pe care îl acordă în expunerea sa - anumitor opinii în chestiunea juridică a feriei. Cu privire la circulația cuvântului și a sensurilor pe care acesta le-a avut în dreptul cutumiar românesc, observațiile filologului şi etimologia pe care a propus-o au fost validate de către cercetările ulterioare38: „V. Bogrea stabilește printr-o largă şi convingătoare

34 George D. Longinescu, Feria, Institutul de Studii și Cercetări Balcanice, București, 1944, p. 18 și urm.

35 Cf. Mihai Vinereanu, Dicționar etimologic al limbii române pe baza cercetărilor de indoeuropenistică, Ed. Alcor Edimpex, București, 2008, p. 354.

36 Termenul cunoaște nu doar în documentele vechiului drept românesc diferite variante de grafie, ci și în analizele care i-au fost dedicate. În ceea ce ne privește, optăm pentru ferie, formă utilizată și în ultima sinteză monumentală în materia istoriei dreptului românesc: Ovid SACHELARIE, Feria, în Ovid SACHELARIE, N. STOICEScu (coord.), „Instituții feudale din țările române. Dicţionar”, Ed. Academiei Republicii Socialiste România, București, 1988, p. 193-194. 37 Vasile BogreA, Din vechea terminologie juridică: Ferîie, p. 347.

38 Ovid SAChelarie, Pronunțarea hotărârii judiciare, în Vladimir Hanga (resp. de vol.), „Istoria dreptului românesc”, vol. I, Ed. Academiei Republicii Socialiste România, București, 1980, p. 418, Valentin Al. Georgescu, Ovid SACHELARIE, Judecata domnească în Țara 
demonstrație lingvistică și extralingvistică, nu numai care este originea lui [...] ci, descoperind etimonul acestor cuvinte, el stabilește și ceea ce au însemnat ele cu adevărat, care a fost sensul lor adevărat, corectând astfel, în acelaşi timp și glosările (uneori, de-a dreptul fanteziste) ale editorilor, culegătorilor39."

Un volum reprezentativ, care să îi cuprindă principalele sale contribuții ştiințifice a apărut foarte târziu, la aproape 50 de ani de la moartea $\mathrm{sa}^{40}$.

\section{Opera literară a lui Vasile Bogrea}

Considerând scrisul ca o datorie de intelectual, deşi cu o operă literară redusă ca volum ${ }^{41}$, Vasile Bogrea a lăsat în urma sa câteva creații de dimensiuni mici. Unele dintre acestea sunt de-a dreptul încântătoare prin scânteierea lor, altele corozive: articole, aforisme ${ }^{42}$, epigrame ${ }^{43}$ şi poeziii44.

Românească și Moldova (1611-1831), partea a II-a, Procedura de judecată, Ed. Academiei Republicii Socialiste România, București, 1982, p. 59.

39 I. MĂRII, op.cit., p. 166.

40 Mircea BorcILĂ, Ion MĂRII, Introducere, în Vasile BogREA, „Pagini istorico-filologice”, p. IX şi urm.

${ }^{41}$ Ele au fost adunate în două volume, deja menționatul Sacra Via, precum și Opere alese, ed. Mircea BorciLĂ ș.a., Ed. Fundației Culturale Române, București/Ed. Ştiința, Chișinău, 1998 (acesta din urmă cuprinde și scrieri ştiințifice, nu doar dintre cele literare şi publicistice). Corespondența lui Vasile Bogrea a făcut obiectul unor publicări parțiale: de exemplu, Documente literare, vol. I, ed. Gh. CARDAȘ, Ed. Minerva, București, 1971, p. 303-315.

42 „A da din coate nu e cu nimic mai uman decât a da din coadă” - Vasile BogrEA, Sacra Via, p. 138.

43 „ « Sunt fiul operelor mele »,/Proclami în lumea lată./Atâta nu-i destul, voinice:/Vezi să le fii și tată” - Vasile BogreA, Epigramă plagiată dlui Ioan Dragu..., în Sacra Via, p. 159.

44 Cea mai tulburătoare poezie a sa este, fără îndoială, Suntem datori pământului, scrisă cu presimțirea sfârşitului său, nu cu mult timp înainte de acesta - N. DRĂGAN, Ultimul cuvânt, în „Societatea de mâine”, nr. 39-40/1926, p. 629. 
Consemnate în fișele sale, calambururile se vor fi risipit în cursurile, conferințele și conversațiile avute, el trecând printre contemporani ca un cozeur neîntrecut 45 .

Din nefericire pentru posteritate, nu cunoaștem să se fi păstrat nici măcar una dintre conferințele sale. „Cine l-a auzit odată, nu-l va uita niciodatăa 4 ” pentru că „verbul său strălucit era numai flacără47”.

\section{Importanța lui Vasile Bogrea în domeniul eticii universitare}

Vasile Bogrea este important pentru ceea ce a lăsat în urma sa și în domeniul eticii universitare. $\mathrm{O}$ aparentă modestă realizare, un cod moral de mici dimensiuni, cu numai cinci reguli, îl face mai actual ca niciodată. Îl vom analiza pe larg în cele ce urmează.

Respectând regula marilor conștiințe morale, scrisul lui Vasile Bogrea era pe potriva vieții sale, el fiind un „caracter pilduitor” și având „o fire de

45 „Ba nu mai știu cine, într-o zi, la cafeneaua Corso, minunându-se de jerbele de scântei ale spiritului pe care le perora Țuțea la masa unde ne aflam, a exclamat: « Ăsta e din școala lui Bogrea! » Cunoscându-l prin urmare pe Țuțea, putem face o inducție despre personalitatea lui Vasile Bogrea, ale cărui conferințe și scrieri cuceriseră atâta lume prin talent și ingeniozitatea ideilor” - Vlaicu BÂRnA, Intre Capşa și Corso, ed. a III-a, Ed. Polirom, Iași, 2014, p. 32.

46 „Era de altfel totdeauna acelaş, în povestirile improvizate ca și’n conferențele anunțate, în convorbirea intimă ca și’n cuvântarea publică: revărsare de aur, nesecată” - Eugeniu SPERANTIA, Vasile Bogrea, în „Cele Trei Crișuri”, nr. 8-9/1936, p. 127.

47 Nicolae MărgineAnu, Mărturii asupra unui veac zbuciumat, ed. Daniela MărgineanuȚăranu, Ed. Fundației Culturale Române, București, 2002, p. 80. Între octombrie 1924 și februarie 1926, profesorul Bogrea a susținut în cadrul Extensiunii, 15 conferințe, niciuna dintre ele repetitivă - a se vedea Florian ȘTEFĂNESCU-GOANGĂ, Istoricul si activitatea „Extensiunii Universitare”, în „Anuarul Extensiunii Universitare din Cluj”, 1924-1925, p. 60-67 și idem, Raport asupra activității desfășurată de „Extensiunea universitară din Cluj” pe anul 19251926, în „Buletinul Extensiunii Universitare din Cluj”, 1925-1926”, p. 63-72. Numărul total al conferințelor lui Vasile Bogrea a fost însă mai mare - a se vedea C. N. MiHALACHE, op.cit., p. 25. 
moralist 48 ” sau - cu alte cuvinte - „un strălucit exemplu al omului de o înaltă valoare etică, pentru care adevărul a fost o pasiune și sacrificiul o datorie49”. $\mathrm{Nu}$ este atunci de mirare că la Bogrea era vizibil „fundamentul de o incoruptibilă etică al tuturor manifestărilor științifice și publice50”. Aceste exigențe morale au determinat „o probitate științifică unică”, care se desprinde până și din medalioanele creionate de el unor personalităţi, opera sa distingându-se prin „soliditatea și amploarea documentării ${ }^{51}$ ”.

$\mathrm{Cu}$ privire la vastitatea documentării, s-a remarcat că amănuntele pe care el le dă la iveală sunt rodul unui travaliu intelectual de mare amploare ce „presupune o adunare a materialului timp de ani de zile, chiar de decenii5"

Paradigma acribiei propusă prin documentările sale amănunțite poate şi trebuie să fie extinsă în toate domeniile cercetării științifice pentru a evita ceea ce el numea „plagiat” involuntar53.

${ }^{8}$ Al. TeOdorescu, Vasile Bogrea, istoric literar şi publicist, în „Anuar de Lingvistică și Istorie Literară”, XXV/1976, p. 187.

49 T. A. Naum, Zece ani de la moartea lui V. Bogrea, p. 510.

50 Nicolae MEcu, Ştiință-conștiință. 110 ani de la nașterea lui Vasile Bogrea, în „Viața Românească”, nr. 9/1991, p. 26-27.

${ }^{51}$ Al. TeOdORESCU, op.cit., p. 187, 191.

$5^{2}$ G. IVĂNESCU, Activitatea lingvistică a lui Vasile Bogrea, în „Anuar de Lingvistică și Istorie Literară”, XXV/1976, p. 183. Iorga remarcase încă din timpul vieții lui Bogrea că acesta era „un om de o erudiție fără păreche, nu numai în filologie, dar și în istoria literară. Cantitatea de informație de care dispune e uimitoare, aproape fantastică" - Nicolae IORGA, Un mare erudit și un suflet ales, apud Vasile BOGREA, SACRA VIA, p. 293. Nu e singurul contemporan uimit de „capacitatea de primire cu totul specială a memoriei sale îi permisese o de-a dreptul monstruoasă acumulare de cunoștințe din mai multe domenii” - N. BuTA, Vasile Bogrea, în „Transilvania”, nr. 10/1926, p. 549. Dintre mărturiile care detaliază proporțiile memoriei lui Bogrea reținem doar una, ilustrativă pe deplin: „Uneori rămâneai cu o impresie de nefiresc: parcă citise tot, și ținea minte tot. Nu numai titluri de cărți și conținuturi, dar amănunte dintre cele mai bizare, până la greșeli de tipar, până la pagină și rând” - G. VÂLSAN, În amintirea lui Vasile Bogrea, în „Societatea de mâine”, nr. 1/1931, p. 3.

53 Vasile BogreA, Contribuție la studiul elementelor orientale din limba română, în „Dacoromania”, I/1920-1921, p. 272. 
Înalta valoare morală pe care a avut-o este atestată și de faptul că „s-a analizat cu luciditate, ba chiar cu cruzime, rar întâlnită la oamenii noştri de știință54”.

În ceea ce privește sancţionarea pentru abateri de la integritatea cercetării, era departe de a fi un Savonarola modern. Cei care l-au cunoscut îndeaproape au reținut că avea „ironia usturătoare cuvenită, îndreptată împotriva falşilor savanți, dar și cea iertătoare pentru cei care păcătuiseră de bună-credință contra unui adevăr științific 55".

Care să fie izvorul unei astfel de conștiințe? O întrebare cu atât mai legitimă cu cât răspunsul poate să dea şi altora posibilitatea să o dobândească. Biografii săi au extras-o dintr-un memoriu pe care Bogrea l-a alcătuit în legătură cu studiul limbilor și literaturilor clasice din gimnaziu și liceu, greaca şi latina: „Nimeni la noi, după Odobescu, nu și-a dat seama mai bine decât Vasile Bogrea că omul moral în cel mai curat și mai nobil înțeles al cuvântului nu se poate forma decât printr'o instrucțiune literară clasică fără nici o

54 G. IVĂNESCU, op.cit., p. 182.

55 C. DAicoviciu, Prefaţă, în Vasile Bogrea, „Pagini istorico-filologice”, p. VI. Posteritatea a consemnat și că „mulți l-au învinuit că a fost rău și necruțător”, însă, după cum s-a observat, nu trebuie ignorat faptul că un „infern a fost viața lui în cei zece ani din urmă, când durerea nu i-a dăruit o zi de liniște fără să-l pedepsească a doua zi cât mai cumplit” - G. VÂLSAN, op.cit., p. 3. Pentru detalii privind problemele de sănătate ale savantului și suportarea lor cu stoicism, a se vedea, de exemplu, Eugeniu SPERANTIA, Vasile Bogrea, în „Scrieri socio-pedagogice”, ed. Codruța Liana Cuceu, Ed. Mega, Cluj-Napoca, 2012, p. 256-260, în care reia din ceea ce publicase la moartea acestuia: „Minunea cea mare fu însă că nici limpezimea minții lui, nici verva lui încântătoare nu s'au resimțit cu nimic de suferințele atroce care-1 sfâșiau. Bogrea nu mai trăia cu trupul ci strălucea, în ciuda trupului” - idem, Vasile BOGREA, în „Cele Trei Crișuri”, nr. 89/1936, p. 127.

În fond, perceperea unei asprimi însoțeşte personalitățile exponențiale. Unele dintre acestea au un caracter considerat incomod pentru că se manifestă intransigent vizavi de jumătăţile de măsură. 
mărginire și fără nici un gând ascuns, că numai aceasta poate crea acea elită intelectuală menită să fie de folos progresului general al societății56."

În afară de pentalog, creația lui Vasile Bogrea în legătură cu problematica eticii este foarte redusă ca întindere; ea mai cuprinde și articole, aforisme și epigrame. Ele trebuie să fie cunoscute pentru că întregesc portretul său de moralist şi întăresc principiile pentalogului universitar. Bunăoară, „un cuvânt, un gând plătește atâta cât plătește cel ce-l rostește. Când Galilei a spus că pământul se mișcă, el a spus, - intelectual, - același gând, pe care-l repetă orice papagal ... ; dar - câtă deosebire! De unde, dacă nu din valoarea etică a vorbitorului 57 ?".

Despre un comportament mai rezervat datorat de către cei care sunt în vârful ierarhiei, Bogrea făcea următoarea observație: „Quod licet Iovi, non licet bovi, - se citează de obicei. Inversa e, poate, mai adevărată: Quod licet bovi, non licet Iovi58".

Ironia lui se dezlănțuie vitriolant atunci când surprinde denaturări ale mediului universitar: „Gravitația universală e un fleac față de gravitaţia universitară” sau „corpul didactic există: rămâne să se înființeze şi spiritul 59”. Venerat de studenți, prețuit de colegi, Bogrea nu lasă neveștejită mizantropia

${ }^{6}$ T. A. Naum, Zece ani de la moartea lui V. Bogrea, p. 507. A se vedea și Nicolae Lascu, Vasile Bogrea - apologet al clasicismului antic, în „Acta Musei Napocensis”, nr. 14/1977, p. 563-567. Pentru textul integral al apologiei, a se vedea Vasile BoGREA, Pentru învățământul clasic. Memoriu redactat cu prilejul proiectului de reforma a învățământului secundar din 1925, Institutul de Arte Grafice „Ardealul”, Cluj, 1925, p. 13.

57 Vasile BogreA, Sacra Via, p. 135.

${ }^{8}$ Ibidem, p. 139. Proverb latin: nu este permis lui Jupiter ceea ce este permis boului (zeul suprem în comparație cu omul de rând sau invers). În antichitate nu se aplicau aceleași reguli persoanelor care proveneau din categorii sociale foarte diferite - Ch. PERELMAN, Justice, Law, and Argument: Essays on Moral and Legal Reasoning, D. Reidel Publishing Company, Dordrecht - Boston - London, 1980, p. 4-5.

59 Vasile BogreA, Sacra Via, p. 141. 
academică: „Mă-mpac cu toți colegii mei, / Pot zice ideal de bine: / O parte nu vorbesc cu mine, / Ceilalți - eu nu vorbesc cu ei ${ }^{60}$ ”.

Exemple din acestea pot continua, desigur nu fără de număr, dar toate la fel de elocvente pentru ideea pe care am vrut să o subliniem, lupta sa pentru o moralitate exemplară.

Deloc surprinzător, ca dovadă a modestiei sale, o reprezintă faptul că „nu s-a gândit că va fi revendicat [între atâtea altele] ca moralist ${ }^{61}$.”

\section{Chestiuni prealabile privind pentalogul universitar al lui Vasile Bogrea}

Ilustrul filolog a conceput un „pentalog universitar”, un veritabil cod moral in nuce. Acest mic cod de etică a fost „alcătuit pentru uz propriu ${ }^{62}$ ”și, din câte cunoaștem, a fost publicat doar postum (a se vedea infra). Nu cunoaștem rațiunile pentru care profesorul Vasile Bogrea a scris regulile acestea. Deși „meseria de a face morală nu cere nici o ucenicie de a fi moral63”, nu credem că avea nevoie de proptelele unor reguli pe hârtie pentru a-și ghida viața, inclusiv cea universitară, profilul său moral fiind unul pe cât de rar, pe atât de imaculat: „Nimic din câte micşorează trudnica noastră existență nu ți s-a putut imputa”, scria un contemporan, aducându-i în formulări vii „prinosul unei dureri ce nu se poate coborî în cuvinte ${ }^{64 "}$.

\footnotetext{
60 Vasile Bogrea, Colegialitate, în „Cele Trei Crișuri”, nr. 1-2/1936, p. 29.

${ }^{61} \mathrm{Al}$. TEODORESCU, op.cit., p. 187.

62 Nicolae MEcU, op.cit., p. 28.

63 Nicolae Iorga, Cugetări, Ed. Tineretului, București, f.a., p. 252.

64 N. BĂNESCU, Durerea colegilor, în „Societatea de mâine”, nr. 39-40/1926, p. 627.
}

128 
Vom analiza pentalogul prin corelare cu dispozițiile Codului de etică în vigoare al universității 65 printre ai cărei profesori fondatori s-a numărat și Vasile Bogrea (astăzi denumită „Babeș-Bolyai” din Cluj-Napoca). Astfel, vom încerca să stabilim dacă şi în ce măsură pentalogul se regăsește în prevederile actuale oficiale ale acestei prestigioase instituții de învățământ superior ${ }^{66}$.

El cuprindea, după cum îi spune și numele, doar cinci reguli esențiale pentru existența unei moralităţi în cadrul raporturilor din Alma mater. Probabil că s-a oprit la acest număr și nu a dublat - să zicem - numărul lor (nu i-ar fi fost greu să o facă, dată fiind spontaneitatea și agerimea spiritului său) pentru a nu se face vreo paralelă nepotrivită cu Decalogul veterotestamentar ${ }^{67}$.

\section{Pentalogul universitar}

Textul pentalogului universitar al lui Vasile Bogrea este concis, formulat simplu și clar, fără echivoc: „1. Să iubești pe studenți. 2. Să nu iubești pe studente. 3. Să știi ce spui, cum spui și cât spui. 4. Să nu uiți hotarele științei

65 Universitatea Babeș-Bolayi, Senatul UBB, H.: 632/SEN/o9.12.2013, Codul de etică și deontologie profesională al Universității Babeş-Bolyai, disponibil la: https://www.ubbcluj.ro/ro/despre/organizare/files/etica/Codul Etic al UBB.pdf.

66 Prin Ordinul ministrului Educației și Cercetării nr. 4492/2005 privind promovarea eticii profesionale în universități, publicat în Monitorul oficial al României, partea I, nr. 595 din 11 iulie 2005, s-a introdus „obligația de a elabora, dezbate și adopta până la data de 20 decembrie 2005 propriul cod de etică universitară”. Pentru cadrul legislativ în materie, a se vedea Simina Elena TĂNĂSESCU, Standarde şi reglementări, în Liviu PAPADIMA (coord.), Deontologie academică. Curriculum-cadru, Ed. Universității din București, București, 2018, p. 37-41, precum şi Valentin MuREȘAN, Mihaela CONSTANTINESCU, De ce avem nevoie de etică şi integritate în mediul academic?, în Emanuel SocAcıU ș.a., „Etică și integritate academică”, Ed. Universității din București, București, 2018, p. 50-52.

67 Ieșirea, 20: 2-17 și Deuteronomul 5: 5-21, „textul fundamental al oricărei etici” - Dicţionar enciclopedic al Bibliei, trad. Dan SlușAnschi, Ed. Humanitas, București, 1998, p. 164. 
și ale minții tale. 5. Să nu uiți că, deasupra talentului și științei, este un lucru incomparabil mai mare: conștiința ${ }^{68}$."

\subsection{Să iubești pe studenți}

Bogrea își iubea elevii/studenții ${ }^{69}$ și, la rândul său, era iubit de aceștia $^{70}$.

Veche aproape de când lumea, dăscălia are și faliții ei, dar și exemple luminoase. Vocația pedagogică este una care se înfăşoară şi se desfăşoară în iubire. Nu poți schimba pe cineva, căci asta înseamnă, în fond, actul de educație, decât dacă îl iubești. Atenție, nu îl schimbi ca să îl iubești! De ce? Pentru că altfel nu e vorba de înțelegere, de susținere, de transmitere a tuturor cunoștințelor, pe care le presupune dăscălia. Iubire fără generozitate nu se poate.

Eșecurile inerente în procesul învățării (nu toți dintr-o grupă sunt eminenți, deși am vrea să fie majoritatea), nu pot fi corijate superior decât prin bunătate, care vine din iubire. Esențialmente, omul este o ființă care iubește, iar în cazul profesiilor vocaționale, cum este și cea de dascăl, iubirea este o condiție sine qua non a actului didactic. Iubirea este, în fond, o valoare etică absolută şi dă un sens superior acțiunilor umane ${ }^{11}$.

\footnotetext{
68 Vasile BogreA, Sacra Via, p. 141.

69 C. DAICOVICIU, op.cit., p. VI; Teodor NAum, Cuvânt înainte, în Vasile BogreA, Sacra Via, p. 6 şi urm.

${ }^{70}$ Liviu Rusu, Durerea foștilor elevi, în „Societatea de mâine”, nr. 39-40/1926, p. 628; I. CONSTANTINESCU, Jalea studenților moldoveni, în „Societatea de mâine”, nr. 39-40/1926, p. 628-629.

71 „Viața anostă, absurdă, plină de antinomii, de sbucium și suferințe, capătă un sens, se regenerează prin iubire” - Mihail UȚă, Filosofia religiei, în „Omagiu Profesorului C. RădulescuMotru”, în „Revista de filosofie”, vol. XVII/1932, p. 501.
} 
Fiecare am păstrat sau vom păstra în mintea şi în sufletul nostru imaginea iconică a câte unui dascăl. Sinteza cea mai reușită cred că o reprezintă cel care transmite știință de carte și împrăștie afecțiune. Cei care lau cunoscut își aduc aminte, bunăoară, de infinita atenție și delicatețe pe care o avea Andrei Hell; profesor de fizică de liceu, care, ani buni după pensionare, mărturisea că îşi făcuse din dăscălie un crez $^{72}$. Şi tot aşa, de infinita generozitate a Profesorului Mircea Mureșan ${ }^{73}$. În preajma lor se simțea pulsul iubirii pe care o aveau pentru oameni.

\subsection{Să nu iubești pe studente}

Formularea este șugubeață, jocul de cuvinte provocând ilaritate atunci când primele două reguli sunt menționate imediat succesiv. Care să fi fost originea intelectuală a acestei reguli? Să fi fost Vasile Bogrea conștient de fascinația pe care o exercita, dar căreia el nu îi căzuse pradă74?

Prin intermediul acestui calambur în legătură cu iubirea, autorul sintetizează, paradoxal, cele două dimensiuni care trebuie să caracterizeze

$7^{2}$ Andrei HELL, Am fost primit cu multă prietenie, cu ospitalitatea caracteristică almăjenilor, în „Almăjana”, nr. 3/2007, p. 2-3 și 47-48 (interviu reluat în Dănilă SITARIU, Valea Almăjului - metaforă a existenței, Ed. Neutrino, Reșița, 2011, p. 356-359); Paul PoPovicI, Silviu Iordan a fost un exemplu pentru noi, p. 603.

73 Profesorul Mircea Mureșan este un „mare dispărut, veșnic prezent în spiritul și inima multora dintre noi, care îi datorăm esența: dragostea pentru dreptul civil" - Paul VASILESCU, Notă asupra ediției, în Mircea MUREȘAN, „Dicționar de drept civil”, ed. postumă îngrijită de Paul Vasilescu ș.a., Ed. Cordial Lex, Cluj-Napoca, 2009, p. 5. Pentru detalii privind viața și activitatea științifică a Profesorului Mircea Mureșan, a se vedea Mircea Dan Bob, Argument, în Mircea Dan Bов (coord.), In memoriam Mircea Mureşan, Ed. Universul Juridic, Bucureşti, 2014, p. 7-8 și Gabriela CHIvU, Mircea Mureșan (1937-2003), în „Studia Universitatis BabeşBolyai. Iurisprudentia”, nr. 2/2003, p. 222-224 (disponibil şi online: http://arhivastudia.law.ubbcluj.ro/articol/457).

74 „Oricare dintre studentele sale ar fi fost prea încântate să-i fie soție” - Nicolae MăRGINEANU, Mărturii asupra unui veac zbuciumat, p. 80. 
raporturile unui dascăl cu studenții săi: afecţiunea față de toți și evitarea oricăror legături neprincipiale cu studentele. Această „regulă” trebuie privită astăzi într-un sens mai larg, incluzând deopotrivă persoanele de sex feminin şi masculin, de o parte și de alta a catedrei.

„Ce păcat că între un bărbat şi o femeie e aşa de grea prietenia gândurilor! Dincolo de zidul formelor pândește primejdia trupurilor75”, avea să scrie moralistul Nicolae Iorga (pe urmele unei întregi literaturi - știinţifice, beletristice sau ascetice - ). Cu mult înainte de consemnarea lui Vasile Bogrea, astfel de relații între participanții la procesul de învățământ nu au reprezentat o noutate ${ }^{76}$, ca de altfel nici atunci și nici astăzi. În literatura de specialitate sa remarcat însă că „interacțiunile romantice dintre studenți și universitari sunt invariabil complicate și periculoase și ar trebui abordate cu prudență 77 ”. Totuși, chiar dacă vorbim de persoane majore, trebuie evitate cu orice preț derapajele, indiferent de natura lor, accidentale sau provocate ${ }^{78}$.

Motivele pentru evitarea unor legături prohibite prin regula a doua a pentalogului sunt mai multe. Dintre acestea, de exemplu, se pot reține: calitatea de mentor, presiunea datorată funcției, notării și a influențării ulterioare a carierei (prin recomandări etc. ${ }^{79}$ )

Într-o asemenea situație este posibilă antrenarea unei părtiniri în ceea ce privește notarea la examen, adică un veritabil conflict de interese. De aceea

75 Nicolae Iorga, Cugetări, p. 111.

${ }^{76}$ A se vedea, bunăoară, Emanuel SocACIU, Constantin ViCĂ, Provocări și dileme, în Emanuel SOCACIU ș.a., op.cit., p. 95.

77 Neil MCARTHUR, Relationships between university professors and students: Should they be banned?, în „Ethics and Education”, nr. 2/2017, p. 2.

78 Demény PETER, Ghidul ipocriților, Ed. Cartea Românească, Bucureşti, 2013, p. 94-96 [capitolul „Elevul/studentul/eleva/studenta ipocrit(ă)”].

79 A se vedea, de exemplu, Lisa BARBELLA, Hot for Teacher: The Ethics and Intricacies of Student-Professor Relationships, în „Sexuality \& Culture”, nr. 1/2010, p. 44 și urm. 
pentru garantarea imparțialității, Codul de etică al UBB reține că ,examinarea de către un cadru didactic a unei persoane care îi este soț/soție, rudă până la gradul al III-lea ori cu care cel ce decide are o relație de afecțiune (s.n.) sau o relație contractuală cu excepția relațiilor contractuale de cercetare academică este de natură să creeze o impresie de favoritism în rândul celorlalți studenți80". Totodată, se reține a fi conflict de interese și alte situații în care imparțialitatea ar putea fi afectată de „relația de afecțiune”: decernarea unui premiu sau a unei distincții ${ }^{81}$, scoaterea la concurs a unui post ${ }^{82}$, încheierea unei relații contractuale ${ }^{83}$, angajarea definitivă sau pe o perioadă de lucru experimentală a unui student ${ }^{84}$. Prin sintagma „relație de afecțiune” este reluată, într-o altă formă şi cu un conținut mai larg, a doua prevedere din pentalogul universitar al lui Vasile Bogrea.

Desigur, dacă „relația de afecțiune” dintre un student și un cadru didactic trebuie să genereze abținerea celui din urmă în cazul examinării, cu atât mai mult, „constituie încălcări ale obligației de integritate pretinderea sau acceptarea de favoruri de orice natură, inclusiv sexuală $88^{8}$.

În fine, oricât de rău famat ar fi un profesor, constituie o încălcare a principiului colegialităţii ,formularea în fața studenților a unor comentarii cu privire la ținuta morală sau a unor aspecte ce țin de viața privată a unui coleg $^{86 ”}$. În cazul constatării unor fapte imorale care afectează universitatea,

\footnotetext{
${ }^{80}$ Art. 17 din Codul de etică al UBB.

${ }^{81}$ Art. 24 lit. a) din Codul de etică al UBB.

82 Art. 24 lit. b) din Codul de etică al UBB.

83 Art. 24 lit. d) din Codul de etică al UBB.

84 Art. 24 lit. e) din Codul de etică al UBB.

85 Art. 16 lit. a) din Codul de etică al UBB.

86 Art. 33 lit. e) din Codul de etică al UBB.
} 
nu studenții reprezintă organismul abilitat să primească plângeri sau reclamațiii în acest sens, ci Comisia de etică a UBB ${ }^{87}$.

\subsection{Să știi ce spui, cum spui și cât spui}

Ce spui poate să se refere la atenția care trebuie acordată transmiterii cunoștințelor astfel încât profesorul să nu altereze „spiritul de dreptate față de ideile pe care le expune”. Aici nu e vorba de a interzice afişarea unor simpatii pentru o anumită idee, operă sau un autor ${ }^{88}$. Însă respectivele afinități sau simpatii „nu are dreptul să le strecoare pieziş în sufletul tineretului. Prin aceasta [profesorul] păcătuiește împotriva funcțiunii lui, care este aceea de a prepara judecata clară și cinstită a tinerilor studenți 89 .

Totodată, să știi ce spui, se poate referi la faptul că profesorul trebuie să fie foarte bine pregătit, la zi cu toate contribuțiile disciplinei pe care o predă. De unde se vede că activitatea de predare nu poate să rămână închisă în sine, ci trebuie să fie strâns legată de cea a cercetării științifice ${ }^{90}$. Altfel cum

\footnotetext{
87 Art. 41 și 43 lit. a) din Codul de etică al UBB.

$88 \mathrm{Cu}$ excepția celor prohibite de lege, adică acelea care au ca efect, de exemplu, instigarea publică (art. 368 C.pen.) sau incitarea la ură sau discriminare (art. 369 C.pen.). În acest sens, a se vedea și dispozițiile Ordonanței de urgență nr. 31/2002 privind interzicerea organizațiilor şi simbolurilor cu caracter fascist, rasist sau xenofob și a promovării cultului persoanelor vinovate de săvârșirea unor infracțiuni contra păcii și omenirii, publicată în Monitorul oficial al României, partea I, nr. 214 din 28 martie 2002.

89 Virgil I. BĂRBAT, „Recomandări” la Universitate ..., Tipografia „Cartea Românească“ S.A., Cluj, 1930, p. 7 .

90 Astăzi există chiar o presiune privind alocarea unui interval de timp mai generos cercetării decât pentru pregătirea actului didactic - Jenay ROBERT, William S. CARLSEN, Teaching and Research at a Large University: Case Studies of Science Professors, în „Journal of Research in Science Teaching”, nr. 7/2017, p. 938. Originea acestei accentuări poate că ar trebui căutată în evaluarea universităţilor (dar și cea a fiecărui cadru didactic universitar), care se face în primul rând în funcție de performanțele științifice (publicații, proiecte de cercetare etc.).
}

\section{4}


să fie la curent cu tot ceea ce se discută în literatura de specialitate? Or, „lipsa de informație precisă [este] dăunătoare la un profesor91".

Astăzi, această regulă a pentalogului se regăsește într-un capitol distinct al Codului de etică al UBB, și anume cel privitor la „Competență și profesionalism”. Desigur, la o altă amploare, generată de receptarea unor probleme general-universitare, întâlnite pretutindeni. Aşadar, regăsim sintetica regulă ce spui într-o enunțare amănunțită și deloc prolixă: „Orice cadru didactic trebuie să stăpânească în detaliu disciplina pe care o predă, asigurându-se că întregul conținut al cursului este actualizat, reprezentativ și adecvat nivelului la care se situează disciplina în planul de învățământ92".

Cum spui, evident că se referă la formă, la retorică și la transmiterea unei stări de spirit auditoriului. Ca şi în cazul altor dascăli faimoşi, cursurile pe care le susținea Bogrea nu atrăgeau doar studenți dornici de învățătură sau lărgirea cunoștințelor ${ }^{93}$, ci şi un auditoriu din afara universității94. Însemnările contemporanilor cuprind revărsări de elogii și în legătură cu prelegerile sale: „Cugetul lui neastâmpărat era într-o veșnică efervescență, și simțind nevoia unei împărtășiri directe, el se slujea de preferință de cuvântul rostit, ca fiind o expresie mai spontană şi mai adecvată ființei sale. Așa se explică de ce a scris relativ puțin. În schimb, ce vorbitor strălucit! Ce « causeur

91 Virgil I. BĂRBAT, „Recomandări” la Universitate ..., p. 27.

92 Art. 9 din Codul de etică al UBB. A se vedea totodată şi „Orice cadru didactic trebuie să acorde o atenție deosebită pregătirii și susținerii cursurilor la orele prevăzute, elaborării, pregătirii sau asigurării materialului didactic necesar studenților pentru curs, seminar sau laborator, ținerii orelor de consultații prevăzute, urmăririi și îndrumării activității de redactare de lucrări (proiecte, lucrări de licență sau disertație) de către studenți, notării și comunicării rezultatelor în termenul prevăzut” - art. 11 din Codul de etică al UBB.

93 „Lecțiile lui Bogrea de limbă, literatură și civilizație latină puteau fi utile pentru Dreptul roman” - Nicolae MĂRgINEANU, Mărturii asupra unui veac zbuciumat, p. 67.

94 Eugeniu Sperantia, Vasile Bogrea, în „Scrieri socio-pedagogice”, p. 255. 
» nesecat! Această însușire făcea din el un dascăl incomparabil, din a cărui gură vrăjită adevărurile cele mai aride se precipitau în haina elegantă a verbului încântător, așezate cu cele mai spirituale observații sau glume ${ }^{95}$ ".

Și cum spui se regăsește astăzi în conținutul unui laborios articol: „Sub aspect pedagogic, competența presupune alegerea celor mai adecvate modalități de tratare a fiecărei teme din cadrul programei, comunicarea obiectivelor cursului, alegerea unor modalități de examinare în concordanță cu aceste obiective. Este, de asemenea, importantă adaptarea stilului de predare la nevoile şi nivelul cursului, precum și la specificul grupului de studenți ${ }^{9}$ ".

Cât spui. Aici nu e vorba nicidecum de a nu oferi totul studenților. Au existat și situații în care accesul studenților la știință și informație a fost redus de către profesor în mod intenționat. De ce? De teama concurenței ulterioare ... Un astfel de dascăl este însă descalificat în esența lui. Valoarea unui dascăl o dau nu doar articolele sau cărțile scrise, ci și emulația pe care o produce în rândul studenților săi. Și, nu cred că poate fi o bucurie mai mare pentru un profesor decât să-și vadă foștii studenți întrecându-l: atunci înseamnă că și-a îndeplinit funcțiunea sa de dascăl. Uneori e mai ușor, alteori e mai greu să îți întreci maestrul, dar întotdeauna această emulație trebuie să provoace, ambelor părți, o bucurie senină.

Un dascăl trebuie să fie lumina studenților săi. Nu doar morală, ci și ştiințifică. Însă acestea amândouă trebuie să fie îngemănate, căci nu se poate una fără cealaltă. Nu poți fi moral netransmițând tot conținutul științific. Vasile Bogrea nu se înscria în categoria de dascăli care, de teama unei

95 Şt. BEZDECHI, op.cit., p. 625.

${ }^{66}$ Art. 12 din Codul de etică al UBB. 
concurențe ulterioare, nu transmit integral cunoștințele. Dimpotrivă, el a fost o sursă de idei pentru alții, colegi de-ai săi, nu doar pentru studenți. De unde rezultă un caracter cu totul special.

Dar să rememorăm mărturia unor contemporani: „Lecțiile sale de la universitate evocau cu măiestrie neîntrecută antichitatea clasică, al cărei interpret desăvârşit era97”. Sau: „ce sursă de sugestii fecunde era pentru colegii săi, conversația lui admirabil documentată cu indicații pe care i-le punea la îndemână cu atâta îmbelșugare fabuloasa lui memorie! Cred că nu greșesc când afirm că valoarea lui de căpetenie, pe lângă şi deasupra aportului pozitiv adus mai ales în istorie şi filologie, stă mai ales în acele sugestii pe care cu atâta dărnicie le-a împărtăşit în jurul său tuturor ce l-au frecventat şi i-au cerut un sfat, o îndrumare în îndoelile lor. Căci ştiința lui era vie şi curgea direct din sursă, ocolind pe cât posibil acest intermediar inert şi de multe ori infidel, care e scrisul98." În sfârșit, răsună încă emoția din cuvintele unui contemporan de-al său: „Comoara de lumină ce radia cu atâta bogăție, cheltuindu-se atât de risipitor ${ }^{9}$ ".

Ne este greu să ne dăm seama ce a vrut să spună Vasile Bogrea atunci când a scris „să știi [...] cât spui”. Este exclusă, în lumina mărturiilor colegilor săi, autocenzura de teama de a nu fi depăşit de discipoli. Dimpotrivă, s-a constatat că era un dascăl total, un coleg cu un altruism rar, şi cu o activitate extrauniversitară foarte bogată. Conferințele organizate prin „Extensia universitară o demonstrează (ele presupuneau un fizic epuizant; să nu uităm că deplasările în epocă nu se făceau cu rapiditatea şi comoditatea de astăzi).

\footnotetext{
97 Silviu Dragomir, La catafalcul lui Vasile Bogrea, în „Societatea de mâine”, nr. 39-40/1926, p. 626.

98 Şt. BEZDECHI, op.cit., p. 625.

99 N. BĂNESCU, op.cit., p. 626.
} 
Cât spui poate fi extras din regula care astăzi privește evitarea unor consecințe negative pentru studenți atunci când aceștia se situează de o parte sau alta în luptele de idei ale cadrelor didactice: „Dezacordurile de natură științifică între cadrele didactice din Universitate nu trebuie să afecteze pregătirea şi rezultatele studenților ${ }^{100 ”}$. În situația în care există dezacorduri grave la nivel științific, unele poate întemeiate, totuşi constituie o încălcare a principiului competenței şi profesionalismului „raportarea negativă la colegi şi la rezultatele lor în cadrul propriilor activităţi de predare ${ }^{101 ”}$. Prin urmare, este exclusă implicarea studenților într-o polemică care, de plano, îi depăşește din punct de vedere al bagajului de cunoștințe, dar și emoțional.

Chiar şi în situaţia în care există argumente obiective care pot sta la baza unei critici severe şi devastatoare a opiniilor unui coleg profesor, nu este etic ca acestea să fie comunicate studenților cu menționarea vreunui nominem odiosa. Într-o asemenea situație, ar fi de recomandat doar o deconstrucție impersonală a acelor rezultate care trebuie neapărat prezentate ca stadiu al cercetărilor sau a unor controverse doctrinare. Textul codului nu înlătură orice discuție ştiințifică şi obiectivă, mai ales acolo când, în opinia unora, s-a greșit grav. Dimpotrivă, oferă chiar soluția pentru a evita o dispută în afara limitelor academice. Astfel, se consideră încălcare a principiului colegialității „discreditarea în mod injust a ideilor, ipotezelor sau rezultatelor cercetărilor unui coleg, fără a ține cont de exigențele presupuse de dezbaterea academică și de principiile argumentării critice nuanțate ${ }^{102}$."

\footnotetext{
${ }^{100}$ Art. 10 din Codul de etică al UBB.

${ }^{101}$ Art. 13 lit. d) din Codul de etică al UBB.

102 Art. 33 lit. c) din Codul de etică al UBB.
} 


\subsection{Să nu uiți hotarele științei și ale minții tale}

Paradoxal(?), nici aici nu era vorba despre persoana autorului. Contemporanii săi au remarcat „bogăția uimitoare a cunoștințelor sale, a trecut, dela început, peste hotarele strâmte ale specialității”. Mai mult, „nu era domeniu al științei, în care mintea sa de largă comprehensiune să nu fi pătruns. Antichitatea n-a avut la noi un cunoscător mai adânc, un evocator mai plin de talent; filologia n-a găsit o intuiție mai sigură, literatura universală un interpret mai fin; și nimeni nu s-a apropiat mai cu drag și mai înțelegător de literatura poporului nostru ${ }^{103 ”}$. Cu toată erudiția sa unanim recunoscută, Vasile Bogrea nu se mulțumea cu ceea ce acumulase şi avea „o sete atât de nepotolită de a-şi mări necontenit cunoștințele ${ }^{104 "}$.

Şi atunci? Şi atunci şi altădată, ba chiar şi astăzi, foarte mulți se aventurau dincolo de granițele științei pe care o stăpâneau, cu o falsă competență doctă, cu ipoteze absurde, cu corelații care, la o privire mai atentă nu stăteau în picioare ... Sau, după cum arată cea de-a doua teză, uitând de „hotarele minții”, adică de limitele inerente ale cunoașterii umane.

Bogrea a sancționat mereu pe cei care au scris despre o anumită chestiune fără a se documenta temeinic în prealabil. În lipsa lecturilor serioase, opiniile exprimate pe marginea unui subiect nu pot fi decât derizorii, receptarea lor făcându-se ... cum grano salis ${ }^{105}$, adică în glumă ${ }^{106}$.

103 N. BĂNESCU, op.cit., p. 626.

104 Sextil PușCARIU, op.cit., p. 1530.

105 Lat.: „cu un grăunte de sare”, cu haz adică. Cu alte cuvinte, „nu trebuie luat în serios ceea ce se spune" - I. BERG, Dicționar de cuvinte, expresii, citate celebre, Ed. Științifică, București, 1968, p. 96.

106 Vasile BogreA, Câteva considerații asupra toponimiei românești, în „Dacoromania”, I/1920-1921, p. 210. 
Contrar accepțiunii lui Socrate, care avea curajul să spună „știu că nu știu nimic”, pe vremea sa, dar și mai târziu, au existat tot felul de speculanți care cădeau în ridicol prin bibliografia sumară consultată și puterea lor redusă de analiză. S-a schimbat ceva între timp?

Pentru că nici profesorii nu se nasc învăţați şi trebuie să se perfecționeze continuu, s-a statuat că „Universitatea se obligă să susțină [...] excelența științifică, profesională, pedagogică ${ }^{107 ” . ~ O r ~ a c e s t e a ~ s u n t ~ p r o c e s e ~}$ continue, care nu ar putea fi asumate de fiecare în mod personal în lipsa constatării limitelor inerente ale științei și rațiunii proprii.

\subsection{Să nu uiți că, deasupra talentului și științei, este un lucru incomparabil mai mare: conștiința}

Plecând de la Solomon, Rabelais notează că „știința fără conștiință este ruina sufletuluii ${ }^{108 ”}$. Această linie de gândire, care nu este proprie doar umanistului francez, a fost modul de a fi al lui Vasile Bogrea și a reprezentat perspectiva sa umanistă în știință109: „A fi obiectiv nu înseamnă, nu poate să însemne a înceta să fii om ${ }^{110}$.”

107 Art. 7 alin. (2) din Codul de etică al UBB.

108 „Nu-ncape înțelepciune în suflet plin de răutate” - François RABELAIs, Gargantua și Pantagruel, trad. Ileana şi Romulus VulPEScu, Ed. Ion Creangă, București, 1989, p. 128-129 (parafrază la „răutatea strâmbă-nțelepciunea” - Cartea înțelepciunii lui Solomon, IV: 11, în „Biblia sau Sfânta Scriptură”, versiune diortosită de Bartolomeu Valeriu ANANIA, Ed. Institutului Biblic și de Misiune al Bisericii Ortodoxe Române, București, 2001, p. 1272). Pentru ideea unei paralele Rabelais-Bogrea, Nicolae MEcU, op.cit., p. 28.

109 Mircea Borcilă, Postfață, în Vasile Bogrea, Sacra Via, p. 327.

110 Vasile BogreA, Sine ira et studio, în Sacra Via, p. 80. 
Deși la un moment dat conscientia est cordis scientia ${ }^{111}$ a părut doar un joc de cuvinte, s-a văzut la ce orori duce știința fără conștiiință ${ }^{112}$.

Lipsa de conștiință a persoanei o transformă pe aceasta într-un infractor, iar pe semeni și societate în victime ${ }^{113}$, indiferent de câte prescripții de conduită și sancțiuni pentru încălcarea acestora ar exista în legislație. De aceea, fără să fie menționată in terminis, conştiința este totuşi izvorul viu al comportamentului moral, al raporturilor etice din cadrul comunității universitare, al respectării şi promovării principiilor fundamentale pe care se bazează codurile de etică în general și Codul de etică al Universității BabeșBolyai, în discuție: „libertate academică, competență şi profesionalism, integritate, onestitate intelectuală, colegialitate, loialitate, dreptate şi echitate, responsabilitate ${ }^{114 "}$.

\section{Concluzii}

Lectura pentalogului universitar descoperă o surpriză la fel de mare ca scânteile pe care le conține: actualitatea sa. De fapt, la Bogrea întreaga operă morală este „neatinsă de trecerea vremii ${ }^{115 ” . ~}$

\footnotetext{
111 Pseudo BERnard, citat după Henri Busson, Rabelæsiana. "Science sans conscience 》 (Pantagruel, VIII), în „Humanisme et Renaissance, nr. 2/1940, p. 238.

112 Din întinsa bibliografie privind Holocaustul, a se vedea, de exemplu, Nyiszli MikLós, Am fost medic la Auschwitz. Morți fără morminte. Laboratorul și crematorïle dr-ului Mengele, trad. Cecilia FoDor, Ed. Aquila '93, Oradea, 1998. Pentru știința dreptului fără conștiință, a se vedea, de exemplu, Bernd RüTHERs, Dreptul degenerat. Teorii juridice şi jurişti proeminenți in cel de-al Treilea Reich, ed. a II-a, reviz. și ad., trad. Marius BăLAN, Ed. Universității „Alexandru Ioan Cuza”, Iași, 2016.

113 Nicolae MĂRgInEANU, Condiția umană, p. 144.

114 Art. 2 din Codul de etică al UBB.

115 Nicolae MEcU, op.cit., p. 29.
} 
Chiar dacă, probabil, pentalogul nu a reprezentat una dintre sursele de inspirație, fiecare regulă din micul cod moral se regăsește astăzi, direct sau indirect, în Codul de etică al Universității Babeș-Bolyai. Inspiratele formulări sintetice ale lui Vasile Bogrea le găsim foarte potrivite pentru a fi diseminate în mediul academic și, de ce nu, de a fi incluse ca un preambul al Codului de etică al UBB tocmai pentru asumarea unei tradiții morale de cea mai bună factură de către una dintre cele mai mari și mai prestigioase instituţii de învățământ superior din România.

\section{Addenda ${ }^{* * *}$}

Pentru a facilita cunoașterea vieții și a operei de excepție a universitarului clujean, recomandăm (mai) tinerilor cititori lectura în primul rând a celor două volume deja amintite:

- Vasile BogrEA, Pagini istorico-filologice, ed. Mircea BORCILĂ, Ion MĂRII, Ed. Dacia, Cluj, 1971, 556 p.

- Vasile BogreA, Sacra Via. Pagini literare și publicistică, ed. Mircea BorcILĂ, V. M. Ungureanu, Ed. Dacia, Cluj, 1973, 351 p.

Dintre articolele scrise de Vasile Bogrea și digitalizate prin strădania colectivului Bibliotecii Centrale Universitare „Lucian Blaga” din Cluj-Napoca, menționăm:

- Din vechea terminologie juridică: Ferîie, în „Anuarul Institutului de Istorie Națională”, II/1923, p. 345-350 (URI:

\footnotetext{
* Mulțumesc domnului Dorin Jorea pentru sugestia de a alcătui această addenda.
}

\section{2}


http://dspace.bcucluj.ro/handle/123456789/4983).

- Despre ferâe, în „Anuarul Institutului de Istorie Națională”, III / 19241925 , $p$. $520-521$

(URI:

http://dspace.bcucluj.ro/handle/123456789/14663).

- Câteva considerații asupra toponimiei românești, în „Dacoromania”, I/1920-1921, p. 210-219

(URI: http://dspace.bcucluj.ro/handle/123456789/4980).

- Originalitatea poeziei romane, în „Anuarul Institutului de Studii Clasice", 1928-1932, partea I, p. 3-32 (URI: http://dspace.bcucluj.ro/handle/123456789/45138).

- Contribuție la studiul elementelor orientale din limba română, în „Dacoromania”, I/1920-1921, p. 272-290 (URI: http://dspace.bcucluj.ro/handle/123456789/4980).

- Cercetări de literatură populară, în „Dacoromania”, II/1921-1922, p. 403-444 (URI: http://dspace.bcucluj.ro/handle/123456789/4977).

- Sfinții medici în graiul și folklorul românesc, în „Dacoromania”, IV/1925-1926, partea I, p. 169-182 (URI: http://dspace.bcucluj.ro/handle/123456789/4986).

- Contribuție la studiul onomatopeelor românești, „Dacoromania”, IV/1925-1926, partea a II-a, p. 882-886 (URI: http://dspace.bcucluj.ro/handle/123456789/4979).

Pentru mărturia directă a unor contemporani, a se vedea cuvântările comemorative reunite sub genericul Doliul Universității din Cluj, în „Societatea de mâine”, nr. 39-40/1926, p. 625-629 (URI: http://dspace.bcucluj.ro/handle/123456789/9324) și G. VÂLSAN, În amintirea lui Vasile Bogrea, în „Societatea de mâine”, nr. 1/1931, p. 3-4 (URI: http://dspace.bcucluj.ro/handle/123456789/9429). 